\title{
Acidic and enzymatic saccharification of waste agricultural biomass for biotechnological production of xylitol
}

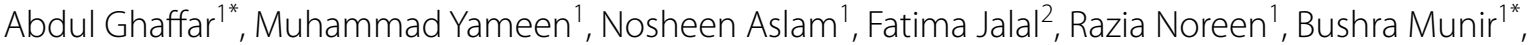 \\ Zahed Mahmood', Sadaf Saleem³ ${ }^{3}$ Naila Rafiq ${ }^{3}$, Sadia Falak , Imtiaz Mahmood Tahir ${ }^{5}$, Muhammad Noman', \\ Muhammad Umar Farooq ${ }^{1}$, Samina Qasim ${ }^{1}$ and Farooq Latif ${ }^{6}$
}

\begin{abstract}
Background: The plant biomass and agro-industrial wastes show great potential for their use as attractive low cost substrates in biotechnological processes. Wheat straw and corn cob as hemicellulosic substrates were acid hydrolyzed and enzymatically saccharified for high xylose production. The hydrolysate was concentrated and fermented by using Saccharomyces cerevisiae and Kluyveromyces for production of xylitol.

Results: Acid hydrolysis of wheat straw and corn cob in combination with enzymatic hydrolysis showed great potential for production of free sugars from these substrates. Kluyveromyces produced maximum xylitol from acid treated wheat straw residues with enzymatic saccharification. The percentage xylitol yield was $89.807 \mathrm{~g} / \mathrm{L}$ and volumetric productivity of $0.019 \mathrm{~g} / \mathrm{L} / \mathrm{h}$. Kluyveromyces also produced maximum xylitol from corn cob acid hydrolyzed liquor with xylitol yield $87.716 \mathrm{~g} / \mathrm{L}$ and volumetric productivity $0.018 \mathrm{~g} / \mathrm{L} / \mathrm{h}$.

Conclusion: Plant and agro-industrial biomass can be used as a carbohydrate source for the production of xylitol and ethanol after microbial fermentation. This study revealed that wheat straw acid and enzyme hydrolyzed residue proved to be best raw material for production of xylitol with S. cerevisiae. The xylitol produced can be utilized in pharmaceuticals after purification on industrial scale as pharmaceutical purposes.
\end{abstract}

Keywords: Acid hydrolysis, Yeast fermentation, Xylitol yield and productivity

\section{Background}

Lignocellulosic agricultural biomass accounts for more than $60 \%$ of the total biomass produced in the form of wheat straw, rice straw, corn cob, corn fibers, para grass, kallar grass and maize stover. Tons of agro-industrial residues are generated annually in agricultural country like Pakistan. This residue contains significant amount of biochemical fractions like cellulose, hemicellulose and lignin to be converted into many valuable products for food and pharmaceuticals [1-3]. Cellulose, hemicellulose and lignin can be acid and enzymatically hydrolyzed

\footnotetext{
*Correspondence: aghaffaruaf@yahoo.com; bushramunirje@hotmail.com 1 Department of Biochemistry, Government College University, Faisalabad 38000, Pakistan

Full list of author information is available at the end of the article
}

and fermented into glucose, mannose, xylose, xylitol, arabinose, acetic acid, glycerol, methanol, methane, butanol, furfural, hydroxyl methyl furfural, 5-hydroxyl methyl furfural, succinic acid and many other products [4-6].

The acid and enzymatic hydrolysis break covalent bonds, hydrogen bonds, van der Waals forces and various intermolecular bridges between sugars. Agricultural biomass such as corn cob and wheat straw was acid hydrolyzed with mild acid $72 \% \mathrm{H}_{2} \mathrm{SO}_{4}$ for production of xylitol [7]. The acid/enzyme $\left(\mathrm{H}_{2} \mathrm{SO}_{4}\right.$, cellulase and xylanase $)$ treatments release sugars which are converted into xylitol after microbial fermentation [3]. Xylitol is identified as one of the twelve high value added chemicals which can be produced from lignocellulosic agricultural biomass through cost effective methods [8]. 
Xylitol is a five carbon polyalcohol sugar having vast applications in food and pharmaceutical industry. It plays an important role to economic grooming of an agricultural country $[9,10]$. It is a sweetening powder like glucose, xylose, fructose and sucrose. Xylitol can be transported into the cell without insulin and can be used as sugar substitute with low calories. It inhibits the growth of tooth decaying microorganisms [11, 12]. It fights against bacterial growth, particularly to Streptococcus. It is digested slowly in the large intestine, reduces the bacterial growth in stomach and plays an important role in oral health $[13,14]$. It can be used for children to prevent middle ear infection (otitis media) and upper respiratory disorders $[9,11,13,15]$. Xylitol helps in the treatment of hypoglycemia, as a sweetener for diabetic patients $[11,12]$. It has no side effect in the human body [16].

The chemical production of xylitol is much expensive due to the requirement of high values of temperature and pressure, therefore, microbial production through fermentation process is more attractive. This process is environmental friendly and doesn't need noxious catalyst. The yeast strain Candida boidinii, Candida parapsilasis, Saccharomyces cerevisiae, Pichia stipites, Kluyveromyces marxianus and Debaryomyces hansenii have been used for xylitol production from different waste agrobiomasses [4, 17-19]. Candida tropicalis has been used for the production of xylitol from corn cob and sugarcane bagasse [20]. Acid treated corn cob and rice straw have been previously fermented into xylitol by using $C$. magnolia, C. guilliermondii and S. cerevisiae [21-25]. This study reports xylitol production by $S$. cerevisiae and Kluyveromyces from easily available biomasses like wheat straw and corn cob.

\section{Methods}

\section{Substrate collection and acid hydrolysis}

Waste agricultural biomass in the form of wheat straw and corn cob was obtained after its seasonal cultivation from local agricultural fields of Faisalabad (Pakistan) and Rafhan Maize Products (Pvt) Limited, Faisalabad (Pakistan). It was dried in oven at $55{ }^{\circ} \mathrm{C}$ for $24 \mathrm{~h}$ and ground to a particle size of $2 \mathrm{~mm}$. The acid hydrolysis of complex polysaccharides present in wheat straw and corn cob was carried out using $72 \% \mathrm{H}_{2} \mathrm{SO}_{4}$ for breakdown of lignocellulosic biomass into different sugar fractions. Wheat straw and corn cob (200 g each) were acid treated with $1 \%(\mathrm{v} / \mathrm{v})$ of $72 \% \mathrm{H} 2 \mathrm{SO} 4$ at a ratio of $1 \mathrm{~g}$ substrate to $5 \mathrm{~mL}$ acidic solution in 2 litter Erlenmeyer flask separately and autoclaved at $121^{\circ} \mathrm{C}$ for $1 \mathrm{~h}$ [15].

\section{Enzymatic saccharification of raw material}

The acid hydrolysis contents were filtered through cheese cloth to separate hydrolysate and residue. The hydrolysate was diluted to $1 \mathrm{~L}$ with distilled water and the residue was dried at room temperature. White precipitates formed during neutralization of hydrolysate with $\mathrm{Ca}(\mathrm{OH})_{2}$ were removed through filtration. One hundred milliliter of hydrolysate was treated with activated charcoal to remove other impurities. The treated hydrolysate was heated at $80{ }^{\circ} \mathrm{C}$ for $30 \mathrm{~min}$. The mixture was cooled at room temperature and filtered using starch powder bed. The total dissolved solids (TDS) were calculated in the liquor.

Acid treated hemicellulosic hydrolysate and residues were enzymatically saccharified using cellulase and xylanase (10-20 U each). The enzymes were added separately to $10 \mathrm{~mL}$ hydrolysate in $250 \mathrm{~mL}$ Erlenmeyer flask along with $25 \mathrm{~mL}$ of $0.1 \mathrm{M}$ citrate buffer and incubated in reciprocal shaker at $50{ }^{\circ} \mathrm{C}$ at $120 \mathrm{rpm}$ for $24 \mathrm{~h}$. The sugar contents in hydrolysate and residue of corn cob and wheat straw were determined using HPLC [26].

\section{Xylitol production}

Acid and enzyme treated wheat straw and corn cob hydrolysate and residue were used separately for xylitol production by the fermentation of S. cerevisiae (hexose fermenting yeast) and Kluyveromyces (pentose fermenting yeast). Kluyveromyces and S. cerevisiae were obtained from Industrial Biotechnology Laboratory, National Institute for Biotechnology and Genetic Engineering (NIBGE), Faisalabad, Pakistan and growing cultures were stabilized through various cycles for uniform growth. Universal yeast media (yeast extract $10 \mathrm{~g} / \mathrm{L}$, peptone $20 \mathrm{~g} / \mathrm{L}$, dextrose $20 \mathrm{~g} / \mathrm{L}$, agar $15 \mathrm{~g} / \mathrm{L}$ for $1 \mathrm{~L}$ ) was used to harbor the yeast strains at $37{ }^{\circ} \mathrm{C}$ in an incubator. The inoculum for each yeast was prepared in $500 \mathrm{~mL}$ Erlenmeyer flask using $200 \mathrm{~mL}$ distilled water, $0.5 \%\left(\mathrm{NH}_{4}\right)_{2} \mathrm{SO}_{4}$ and $\mathrm{MgSO}_{4} \cdot 7 \mathrm{H}_{2} \mathrm{O}, 0.05 \% \mathrm{KH}_{2} \mathrm{PO}_{4}, 0.01 \% \mathrm{CaCl}_{2} \cdot 2 \mathrm{H}_{2} \mathrm{O}$, $0.1 \%$ yeast extract and $3 \% \mathrm{D}$-xylose in an incubator shaker at $37{ }^{\circ} \mathrm{C}$ and $120 \mathrm{rpm}$ for $12 \mathrm{~h}\left[\mathrm{OD}_{600}=1.3-1.5\right.$ $\left(10^{6}\right.$ spores $\left.\left./ \mathrm{mL}\right)\right]$. Sterilized substrates, treated with acid and enzyme were inoculated with $10^{5}-10^{6}$ cells $/ \mathrm{mL}$ separately. All these flasks were placed in shaking incubator at $30{ }^{\circ} \mathrm{C}(120 \mathrm{rpm})$. Samples were obtained after 0, 4, 8, 12, 24,48 and $72 \mathrm{~h}$ of fermentation for further analysis [15].

\section{Analysis of fermented products}

The acid/enzyme hydrolysis hemicellulosic hydrolysate and residue after microbial fermentations were analyzed to determine the concentration of sugars, xylitol and ethanol using HPLC. 


\section{HPLC system and conditions}

High performance liquid chromatography system of Perkin Elmer (USA) equipped with BioRad Aminex HPX$87 \mathrm{H}$ column with corresponding guard column and variable wavelength diode array detector was used to determine the concentration of sugars, xylitol and ethanol. The mobile phase consisted of $0.001 N$ sulphuric acid. A series of calibration standards containing xylose, glucose and xylitol were prepared and filtered through $0.2 \mu \mathrm{m}$ membrane filter. Twenty microliters of each standard was analyzed by HPLC at a flow rate of $0.6 \mathrm{~mL} /$ min, column temperature $65-75{ }^{\circ} \mathrm{C}$ for a retention time of 15 and $20 \mathrm{~min}$. The samples were appropriately diluted, filtered and analyzed in the same way.

\section{Statistical analysis}

The obtained HPLC chromatogram results were statistically analyzed for calculation of \% yield, volumetric productivity and Qs.

\section{Results and discussion}

Wheat straw and corn cob on acid and enzyme hydrolysis produced sufficient amount of carbohydrates for use as substrate to produce xylitol. The enzyme coupled acid hydrolysis showed promising increase in liberating carbohydrate monomers from cellulose and hemicellulose. Xylose, glucose and cellobiose were the principal components in acid hydrolysate of wheat straw and corn cob (Table 1).

Wheat straw and corn cob acid hydrolysis of liquor showed that xylose was present as a major sugar fraction 25.183 and $25.039 \mathrm{~g} / \mathrm{L}$, respectively. Second major fraction found in both the liquors was glucose 3.594 and $2.350 \mathrm{~g} / \mathrm{L}$ respectively. Glucose was present in higher concentration in wheat straw than corn cob. The other sugar fractions found in minor amount was cellobiose 0.058 and $0.014 \mathrm{~g} / \mathrm{L}$, respectively.

Acid and enzyme hydrolysis of wheat straw liquor produced xylose $27.772 \mathrm{~g} / \mathrm{L}$, glucose $3.947 \mathrm{~g} / \mathrm{L}$ and cellobiose $0.209 \mathrm{~g} / \mathrm{L}$ which shows that xylose was the major sugar component (Table 2). The xylose was converted into xylitol by pentose utilizing yeast Kluyveromyces. The xylitol and glucose were used by the yeast as carbohydrate source for its metabolism, growth and energy

Table 1 Carbohydrate contents of wheat straw and corn cob acid hydrolyzed liquor

\begin{tabular}{llll}
\hline Substrate & Xylose $\mathbf{g} / \mathbf{L}$ & Glucose $\mathbf{g} / \mathbf{L}$ & Cellobiose $\mathbf{~} / \mathbf{L}$ \\
\hline W.S.A.H.L & 25.183 & 3.594 & 0.058 \\
C.C.A.H.L & 25.039 & 2.350 & 0.014 \\
\hline
\end{tabular}

W.S.A.H.L*, wheat straw acid hydrolyzed liquor; C.C.A.H.L**, corn cob acid hydrolyzed liquor production. Kluyveromyces yeast on fermentation produced xylitol $3.659 \mathrm{~g} / \mathrm{L}$ with yield percentage of $65.56 \mathrm{~g} / \mathrm{L}$ and volumetric productivity of $0.014 \mathrm{~g} / \mathrm{L} / \mathrm{h}$ after $48 \mathrm{~h}$ (Fig. 1). The rate of substrate consumption (Qs) showed that the yeast used $0.116 \mathrm{~g} / \mathrm{L}$ of xylose during the microbial metabolism to ferment the xylose to xylitol.

Saccharomyces cerevisiae on fermentation in same conditions produced xylitol $3.064 \mathrm{~g} / \mathrm{L}$ having yield percentage of $83.578 \mathrm{~g} / \mathrm{L}$ and volumetric productivity of $0.017 \mathrm{~g} / \mathrm{L} / \mathrm{h}$ after $48 \mathrm{~h}$. The Qs showed that the yeast used $0.076 \mathrm{~g} / \mathrm{L} / \mathrm{h}$ of xylose during the microbial metabolism to ferment xylose to xylitol.

Wheat straw acid and enzyme hydrolyzed residue contained xylose $27.382 \mathrm{~g} / \mathrm{L}$ and glucose $3.044 \mathrm{~g} / \mathrm{L}$ which showed xylose as a major sugar fraction. This xylose was converted to xylitol $19.639 \mathrm{~g} / \mathrm{L}$ with yield percentage of $85.242 \mathrm{~g} / \mathrm{L}$ and volumetric productivity of $0.018 \mathrm{~g} / \mathrm{L} / \mathrm{h}$ after $48 \mathrm{~h}$ by Kluyveromyces at $\mathrm{pH}$ 7. The Qs showed that $0.480 \mathrm{~g} / \mathrm{L} / \mathrm{h}$ of xylose was used by yeast during the metabolism to ferment xylose to xylitol (Table 2).

Kluyveromyces produced xylitol $24.592 \mathrm{~g} / \mathrm{L}$ from acid and enzyme hydrolyzed wheat straw residue with yield percentage of $89.807 \mathrm{~g} / \mathrm{L}$ and volumetric productivity of $0.019 \mathrm{~g} / \mathrm{L} / \mathrm{h}$ after $48 \mathrm{~h}$ of fermentation at $\mathrm{pH}$ 6. The Qs showed that the microorganism used $0.570 \mathrm{~g} / \mathrm{L} / \mathrm{h}$ of xylose for production of xylitol.

Corn cob acid and enzyme hydrolyzed liquor contained xylose and glucose 28.894 and $0.017 \mathrm{~g} / \mathrm{L}$, respectively. Kluyveromyces upon fermentation produced xylitol yield percentage of $87.716 \mathrm{~g} / \mathrm{L}$ and volumetric productivity of $0.018 \mathrm{~g} / \mathrm{L} / \mathrm{h}$ after $48 \mathrm{~h}$. The Qs show that the microorganism used $0.130 \mathrm{~g} / \mathrm{L}$ of xylose for production of xylitol. $S$. cerevisiae fermentation of corn cob acid and enzyme hydrolyzed liquor produced xylitol yield percentage of $41.282 \mathrm{~g} / \mathrm{L}$ and volumetric productivity of $0.009 \mathrm{~g} / \mathrm{L} / \mathrm{h}$ in same time period. The Qs show that $0.227 \mathrm{~g} / \mathrm{L} / \mathrm{h}$ xylose were used by yeast to ferment xylose to xylitol.

Corn cob acidic and enzymatic hydrolysis residue produced xylitol yield percentage of $31.596 \mathrm{~g} / \mathrm{L}$ and volumetric productivity of $0.007 \mathrm{~g} / \mathrm{L} / \mathrm{h}$ after $48 \mathrm{~h}$ of fermentation with yeast Kluyveromyces at $\mathrm{pH}$. The Qs show that the microorganism used $0.374 \mathrm{~g} / \mathrm{L} / \mathrm{h}$ of xylose during convwersion of xylose to xylitol. However, at $\mathrm{pH} 7$, Kluyveromyces produced xylitol yield percentage of $18.542 \mathrm{~g} / \mathrm{L}$ and volumetric productivity of $0.004 \mathrm{~g} / \mathrm{L} / \mathrm{h}$ with Qs $0.403 \mathrm{~g} / \mathrm{L} / \mathrm{h}$.

\section{Discussion}

The aim of this study was to evaluate the utilization of agriculture biomass for the production of value added products like xylitol, beneficial for health, environment and economy. Wheat and corn are major crops of Pakistan which produce a large amount of waste 


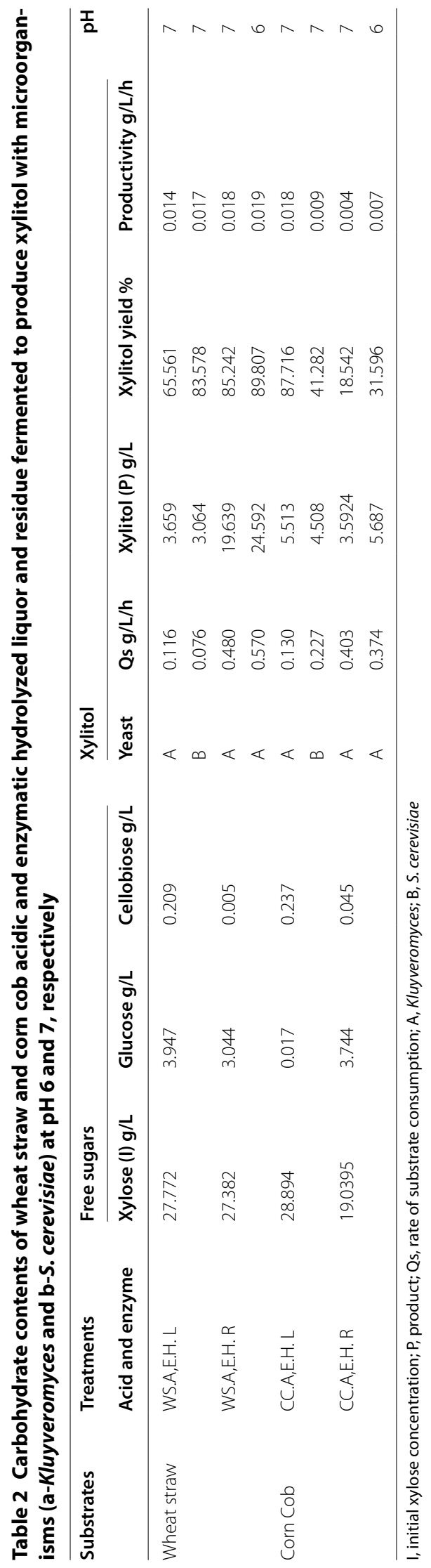




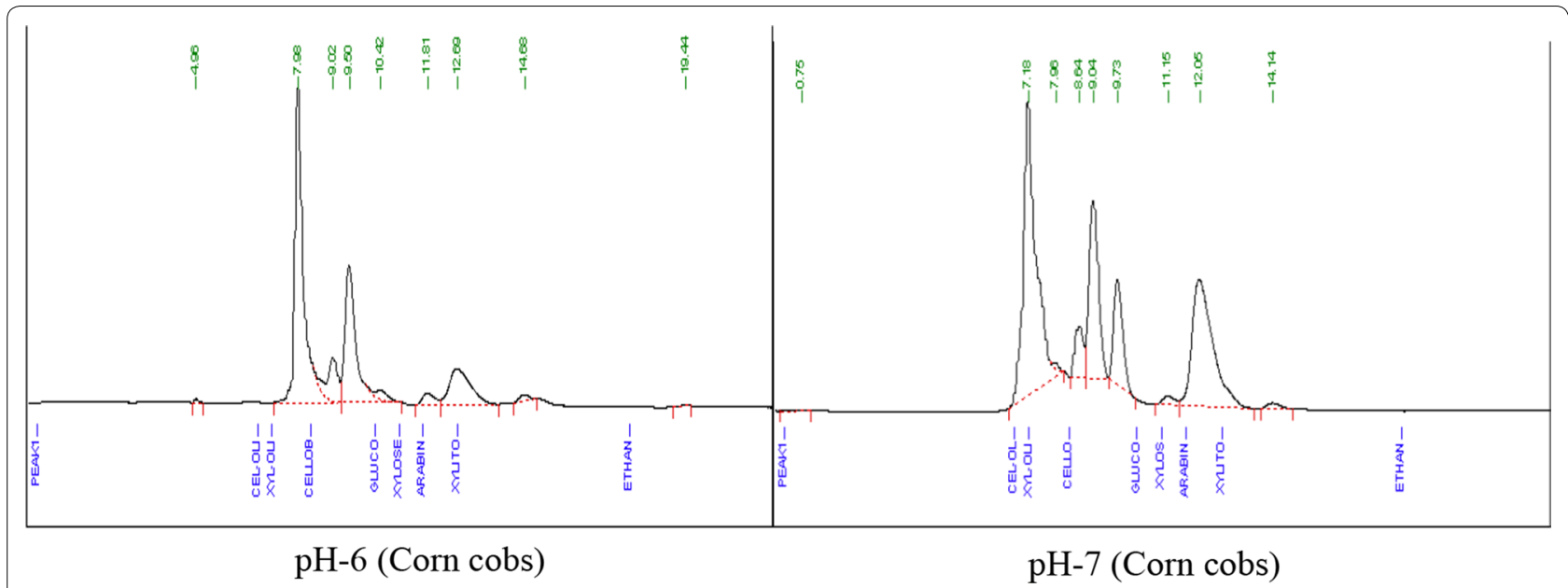

Fig. 1 HPLC Chromatogram carbohydrate contents of wheat straw and corn cobs acid hydrolyzed and enzymatic scarified residues fermented to produce xylitol

residues. Xylose and glucose were the major sugar fractions $(25.183$ and $3.594 \mathrm{~g} / \mathrm{L})$ in wheat straw acid hydrolysate. The enzyme saccharification of this hydrolysate raised the concentrations of xylose up to $27.772 \mathrm{~g} / \mathrm{L}$. The concentration of xylose was reported to be $37 \mathrm{~g} / \mathrm{L}$ when wheat straw was treated with $\mathrm{H}_{2} \mathrm{SO}_{4}$ [27].

Corn cob acid hydrolysate also produced almost similar amounts of xylose $(25.039 \mathrm{~g} / \mathrm{L})$ with a less amount glucose $(2.350 \mathrm{~g} / \mathrm{L})$. However, xylanase saccharification of corn cob acid hydrolysate increased the concentration of xylose up to $28.894 \mathrm{~g} / \mathrm{L}$. The concentration of xylose was reported $23.3 \mathrm{~g} / \mathrm{L}$ when substrate treated with acid $\mathrm{H}_{2} \mathrm{SO}_{4}$ which showed relatively low amount of xylose after acid and enzymatic hydrolysis [28]. The xylitol percentage yield from wheat straw acid and enzyme hydrolysate was $65.561 \mathrm{~g} / \mathrm{L}$ by yeast Kluyveromyces as compared to xylitol $0.59 \mathrm{~g} / \mathrm{g}$ when substrate was fermented by yeast strain $C$. guilliermondii FTI 20037 [22]. Similar results have been reported in another study for production of almost equal amount of xylitol after $48 \mathrm{~h}$ of fermentation under specific conditions [27].

Wheat straw acid and enzyme hydrolysate liquor fermented with S. cerevisiae, produced xylitol $83.578 \mathrm{~g} / \mathrm{L}$ and volumetric productivity of $0.017 \mathrm{~g} / \mathrm{L} / \mathrm{h}$ compared to xylitol $13.7 \mathrm{~g} / \mathrm{L}$ when wheat straw was fermented by Debaryomyces hansenii [28]. The present study reveals efficient production of xylitol from wheat straw acid and enzyme hydrolyzed liquor by S. cerevisiae [29]. The microorganism being hexose fermenting yeast also produced ethanol $38.576 \mathrm{~g} / \mathrm{L}$ and volumetric productivity of $0.803 \mathrm{~g} / \mathrm{L} / \mathrm{h}$ (Ghaffar A. unpublished results). The wheat straw acid and enzyme hydrolyzed residue showed maximum percentage xylitol yield of $89.810 \mathrm{~g} / \mathrm{L}$ and volumetric productivity $0.0187 \mathrm{~g} / \mathrm{L} / \mathrm{h}$ after $48 \mathrm{~h}$ fermentation at
pH 6 and $37^{\circ} \mathrm{C}$ by Kluyveromyces. Corn cob acid and enzyme hydrolyzed liquor showed promising results for production of xylitol percent yield of $87.716 \mathrm{~g} / \mathrm{L}$ and volumetric productivity of $0.0183 \mathrm{~g} / \mathrm{L} / \mathrm{h}$ by Kluyveromyces at $\mathrm{pH}$ 7. The present study shows high amount of xylitol as compared to $0.71 \mathrm{~g} / \mathrm{g}$ xylitol using yeast strain $S$. cerevisiae while $0.50 \mathrm{~g} / \mathrm{g}$ of xylitol from corn cob with C. tropicalis after $72 \mathrm{~h}$ fermentation [30].

\section{Conclusion}

The present study reported the comparison of two substrates (wheat straw and corn cob) and two yeasts (Kluyveromyces and S. cerevisiae) for xylitol production. Wheat straw acid and enzyme hydrolyzed residue was better xylitol producing substrate for S. cerevisiae followed by corn cob acid and enzyme hydrolyzed liquor for Kluyveromyces. The results proved that S. cerevisiae (hexose fermenting yeast) give high yield and volumetric productivity of xylitol and ethanol than Kluyveromyces (a pentose fermenting yeast), respectively. The effect of $\mathrm{pH}$ on Kluyveromyces showed that the xylitol yield and productivity was higher under $\mathrm{pH} 6$ than $\mathrm{pH}$ 7. This may be due to additional utilization of glucose for production of xylitol using hexose monophosphate shunt. The acid treated residue after enzymatic saccharification is first time reported for yeast fermentation to produce xylitol. The xylitol produced can be utilized further after the purification on industrial scale for the pharmaceutical purposes.

\section{Abbreviations}

C.C.A.H.L: corn cobs acid hydrolyzed liquor; C.C.A.H.R: corn cobs acid hydrolyzed residue; C.C.A.E.H.L: corn cobs acid and enzyme hydrolyzed liquor; C.C.A.E.H.R: corn cobs acid and enzyme hydrolyzed residue; W.S.A.H.L: wheat 
straw acid hydrolyzed liquor; W.S.A.H.R: wheat straw acid hydrolyzed residue; W.S.A.E.H.L: wheat straw acid and enzyme hydrolyzed liquor; W.S.A.E.H.R: wheat straw acid and enzyme hydrolyzed residue; Yeast (A): Kluyveromyces (pentose fermenting yeast); Yeast (B): S. cerevisiae (hexose fermenting yeast).

\section{Authors' contributions}

$A G$ and $M Y$ have equal contribution in the study and must be considered as first authors. AG and BM conceived, designed and overall supervised the study; MY and NA performed experimental; FJ and RN acid hydrolyzed the substrates. ZM analyzed the samples on HPLC. AG, SS and NR prepared the manuscript; SF and IMT reviewed and edited the manuscript; MN, UF and SQ assisted in experimental work; FL provided enzymes, yeasts and laboratory space for work. All authors read and approved the final manuscript.

\section{Author details}

${ }^{1}$ Department of Biochemistry, Government College University, Faisalabad 38000, Pakistan. ${ }^{2}$ Department of Zoology and Fisheries, Government College University, Faisalabad 38000, Pakistan. ${ }^{3}$ Department of Chemistry, Government College for Women University, Faisalabad 38000, Pakistan. ${ }^{4}$ School of Pharmacy, University of Faisalabad, Faisalabad 38000, Pakistan. ${ }^{5}$ College of Allied Health Professionals, Government College University, Faisalabad 38000, Pakistan. ${ }^{6}$ Industrial Biotechnology Division, National Institute for Biotechnology and Genetic Engineering (NIBGE), 577, Faisalabad, Pakistan.

\section{Acknowledgements}

The authors acknowledge research facilities provided by National Institute for Biotechnology and Genetic Engineering (NIBGE) Faisalabad. The study makes M. Phil thesis of Muhammad Noman.

\section{Competing interests}

First two authors have over all equal contribution towards this research article and should be considered as first authors.

\section{Funding}

No funding was obtained from any funding agency.

\section{Publisher's Note}

Springer Nature remains neutral with regard to jurisdictional claims in published maps and institutional affiliations.

Received: 9 September 2016 Accepted: 22 September 2017 Published online: 02 October 2017

\section{References}

1. Kataria R, Ruhal R, Babu R, Ghosh S (2013) Saccharification of alkali treated biomass of Kans grass contributes higher sugar in contrast to acid treated biomass. Chem Eng J 230:36-47

2. Sarkar N, Ghosh SK, Bannerjee S, Aikat K (2012) Bioethanol production from agricultural wastes: an overview. Renew Energ 37:19-27

3. Bilal M, Asgher M, lqbal HM, Hu H, Zhang X (2017) Biotransformation of lignocellulosic materials into value-added products - a review. Int J Biol Macromol 98:447-458

4. Anwar Z, Gulfraz M, Irshad M (2014) Agro-industrial lignocellulosic biomass a key to unlock the future bio-energy: a brief review. J Radiat Res Appl Sci 7:163-173

5. Reith JH, Den Uil H, Van Veen H, De Laat WT, Niessen JJ, De Jong E, Elbersen HW, Weusthuis R, Van Dijken JP, Raamsdonk L, BV RN (2014) Co-production of bio-ethanol, electricity and heat from biomass residues. In proceedings of the 12th European conference on biomass for energy, industry and climate protect, p 17-21

6. Leathers TD, Dien BS (2000) Xylitol production from corn fibre hydro lysates by a two-stage fermentation process. Process Biochem 35:765-769

7. Li Z, Guo X, Feng X, Li C (2015) An environment friendly and efficient process for $x y$ litol bioconversion from enzymatic corncob hydrolysate by adapted Candida tropicalis. Chem Eng J 1(263):249-256
8. Santos DT, Sarrouh BF, Rivaldi JD, Converti A, Silva SS (2008) Use of sugarcane bagasse as biomaterial for cell immobilization for xylitol production. $J$ of Food Eng 86:542-548

9. Mäkinen KK (2000) Can the pentitol-hexitol theory explain the clinical observations made with xylitol? Med hypotheses 54:603-613

10. Yoshitake J, Ohiwa H, Shimamura M, Imai T (1971) Production of polyalcohol by a Corynebacterium sp. Part I. Production of pentitol from aldopentose. Agric Biol Chem 35:905-911

11. Ping Y, Ling HZ, Song G, Ge JP (2013) Xylitol production from nondetoxified corncob hem 1 icellulose acid hydrolysate by Candida tropicalis. Biochem Eng J 75:86-91

12. Khaled AR, Butfiloski EJ, Sobel ES, Schiffenbauer J (1998) Use of phosphorothioate-modified oligodeoxynucleotides to inhibit NF-KB expression and lymphocyte function. Clin Immunol Immunopathol 86:170-179

13. Uhari M, Tapiainen T, Kontiokari T (2000) Xylitol in preventing acute otitis media. Vaccine 19:144-147

14. Aranda-Barradas JS, Garibay-Orijel C, Badillo-Corona JA, Salgado-Manjarrez E (2010) A stoichiometric analysis of biological xylitol production. Biochem Eng J 50:1-9

15. Latif F, Rajoka MI (2001) Production of ethanol and xylitol from corn cobs by yeasts. Bioresource Technol 77:57-63

16. Nigam P, Singh D (1995) Processes of fermentative production of xylitola sugar substitute. Proc Biochem 30:117-124

17. Wang H, Li L, Zhang L, An J, Cheng H, Deng Z (2016) Xylitol production from waste xylose mother liquor containing miscellaneous sugars and inhibitors: one-pot biotransformation by Candida tropicalis and recombinant Bacillus subtilis. Microb Cell Fact 15:1-82

18. Rodrigues RC, Kenealy WR, Jeffries TW (2011) Xylitol production from DEO hydrolysate of corn stover by Pichia stipitis YS-30. J of Ind Microbiol Biotechnol 38:1649-1655

19. Rao RS, Jyothi CP, Prakasham RS, Sarma PN, Rao LV (2006) Xylitol production from corn fiber and sugarcane bagasse hydrolysates by Candida tropicalis. Bioresource Technol 97:1974-1978

20. Kogje AB, Ghosalkar A (2017) Xylitol production by genetically modified industrial strain of Saccharomyces cerevisiae using glycerol as co-substrate. J Ind Microbiol Biotechnol 10:1-11

21. de Albuquerque TL, Gomes SD, Marques JE Jr, da Silva Jr IJ, Rocha MV (2015) Xylitol production from cashew apple bagasse by Kluyveromyces marxianus CCA510. Catal Today 255:33-40

22. Huang CF, Jiang YF, Guo GL, Hwang WS (2011) Development of a yeast strain for xylitol production without hydrolysate detoxification as part of the integration of co-product generation within the lignocellulosic ethanol process. Bioresource Technol 102:3322-3329

23. Oh EJ, Ha SJ, Kim SR, Lee WH, Galazka JM, Cate JH, Jin YS (2013) Enhanced xylitol production through simultaneous co-utilization of cellobiose and xylose by engineered Saccharomyces cerevisiae. Metab Eng 15:226-234

24. Chandel AK, Singh OV, Rao LV (2010) Biotechnological applications of hemicellulosic derived sugars: state-of-the-art. In sustainable biotechnology. Springer, Netherlands, pp 63-81

25. Canilha L, Carvalho W, Felipe MD (2008) Xylitol production from wheat straw hemicellulosic hydrolysate: hydrolysate detoxification and carbon source used for inoculum preparation. Braz I Microbiol 39:333-336

26. Agblevor FA, Hames BR, Schell D, Chum HL (2007) Analysis of biomass sugars using a novel HPLC method. Appl Biochem Biotech 136:309-326

27. Guo GL, Chen WH, Chen WH, Men LC, Hwang WS (2008) Characterization of dilute acid pretreatment of silver grass for ethanol production. Bioresource Technol 99:6046-6053

28. Pérez-Bibbins B, Salgado JM, Torrado A, Aguilar-Uscanga MG, Domínguez JM (2013) Culture parameters affecting xylitol production by Debaryomyces hansenii immobilized in alginate beads. Proc Biochem 48:387-397

29. Li Z, Qu H, Li C, Zhou X (2013) Direct and efficient xylitol production from xylan by Saccharomyces cerevisiae through transcriptional level and fermentation processing optimizations. Bioresource Technol 149:413-419

30. Misra S, Gupta P, Raghuwanshi S, Dutt K, Saxena RK (2011) Comparative study on different strategies involved for xylitol purification from culture media fermented by Candida tropicalis. Sep and Purif Technol 78:266-273 